\title{
Roadmap for operational sustainability: an approach based on Integrated Management Systems and Business Process Management
}

Camila dos Santos Ferreira ${ }^{1}$, São Carlos School of Engineering, University of São Paulo, São Paulo, Brazil Camila Fabricio Poltronieri², Goias Federal University. Goiânia, Brazil

Diego Rodrigues Iritani ${ }^{3}$, Upcycle: Circular Economy Consulting, Brazil

Mônica Tani Vicente ${ }^{4}$, São Carlos School of Engineering, University of São Paulo, São Paulo, Brazil

Stefano de Nadai ${ }^{5}$, São Carlos School of Engineering, University of São Paulo, São Paulo, Brazil

Aldo Roberto Ometto ${ }^{6}$, São Carlos School of Engineering, University of São Paulo, São Paulo, Brazil

Mateus Cecílio Gerolamo 7 , São Carlos School of Engineering, University of São Paulo, São Paulo, Brazil

Luiz Cesar Ribeiro Carpinetti ${ }^{8}$, São Carlos School of Engineering, University of São Paulo, São Paulo, Brazil

\section{RESUMO}

Objetivo - Este artigo propõe um roadmap para a sustentabilidade nas operações com base em princípios e práticas de Sistema de Gestão Integrado (SGI) e Business Process Management (BPM).

Referencial teórico - As empresas consideram seus resultados baseados nas dimensões econômica, ambiental e social desta forma, alguns pesquisadores apontam a contribuição do SGI para a sustentabilidade. Outro aspecto importante da mudança para modelos de negócios mais sustentáveis é a estrutura organizacional. O BPM foca na implementação da gestão horizontal da organização por meio de processos de negócios.

Metodologia - Diante deste contexto, foi realizada uma revisão sistemática da literatura (SLR), a fim de identificar princípios, práticas e técnicas de IMS e BPM, seguidos da elaboração do roteiro e da pesquisa de campo com especialistas.

Conclusões - Os resultados da pesquisa de campo indicam que o roteiro representa uma estrutura que pode apoiar as organizações a alcançar seus objetivos de sustentabilidade.

Limitações / implicações da pesquisa - Uma das limitações do estudo foi o número reduzido de especialistas que analisaram o roteiro, desta forma, sugere-se consultar outros especialistas. Outra limitação é o fato de o estudo ter que avançar nas questões de implementação apresentadas pelo roteiro proposto. Nesse sentido, um estudo adicional deve ser realizado para abordar esse ponto.

Originalidade - Esta pesquisa utiliza conceitos já consolidados na literatura (SGI e BPM) como suporte para empresas que buscam se tornar mais sustentáveis.

Palavras-chave: Sistema de gestão Integrado; Gerenciamento de processos de negócios; Roteiro; Sustentabilidade; IMS; BPM.

\section{ABSTRACT}

Purpose - This paper proposes a roadmap for the sustainability of operations based on the principles and practices taken from Integrated Management Systems (IMS) and Business Process Management (BPM).

Theoretical framework - Companies must consider results based on the economic, social, and environmental dimensions of the Triple Bottom Line, and as such, some researchers point to the contribution made by IMS for sustainability. Another important aspect of changing to more sustainable business models is organizational structure. BPM focuses on implementing horizontal management in the organization through business processes.

Design/methodology/approach - Within this context, a Systematic Literature Review (SLR) was carried out to identify IMS and BPM principles, practices and techniques, then a roadmap was designed and field research was carried out by specialists.

Findings - Field research findings indicate that the roadmap represents a framework which can support organizations to achieve their sustainability goals.

Research limitations/implications - One of the limitations in the study was the reduced number of specialists who analyzed the roadmap. Therefore, it is suggested, as a further study, that this roadmap is validated by other experts, including people from other countries. Another limitation is that the study must progress further on the issues of implementation posed by the proposed roadmap. As such, a further study should be carried out to address this point.

Originality/value - This study uses concepts that have already been consolidated in the literature (IMS and BPM) as support for companies that seek to become more sustainable.

Key words - Integrated Management System; Business Process Management; Roadmap; Sustainability; IMS; BPM.

1. Rodovia Domingos Innocentini, km 13, Itirapina, São Paulo, Brazil, ferreira.camila@ usp.br, https://orcid.org/0000-0003-2530-8020; 2. camilafabricio@ufg.br, https://orcid.org/0000-0001-5829-2462; 3. diegoiritani@gmail.com, https://orcid.org/0000-0003-0620-8956; 4. monitvicente@gmail.com, https://orcid.org/0000-0002-3915-5582; 5. barbara.bezerra@ unesp.br, https://orcid.org/0000-0002-84594664stefanodn012@gmail.com, https://orcid.org/0000-0002-2507-1257; 6. aometto@sc.usp.br, https://orcid.org/0000-0003-3577-5175; 7. gerolamo@sc.usp.br, https://orcid.org/0000-0002-6535-0904; 8. carpinet@sc.usp.br, ttps://orcid.org/0000-0002-8357-2607.

FERREIRA, C.S.; POLTRONIERI, C.F.; IRITANI, D.R.; VICENTE, M.T.; NADAI, S.; OMETTO, A.R.; GEROLAMO, M.C.; CARPINETTI, L.C.R. Roadmap for operational sustainability: an approach based on Integrated Management Systems and Business Process Management. GEPROS. Gestão da Produção, Operações e Sistemas, v.16, nº 41 p. 181- 212, 2021.

DOI: $\underline{\text { http://dx.doi.org/10.15675/gepros.v16i1.2753 }}$ 


\section{INTRODUCTION}

In order to address sustainability, companies have to consider the triple bottom line's dimensions, economic, social and environmental (ELKINGTON, 1998). Sustainability has been increasingly attracting attention of academics and practitioners (LINNENLUECKE; GRIFFITHS, 2010). According Kiron et al. (2017), around 90\% of executives see sustainability as important and 50\% of companies have changed their business models for reach sustainability. These companies do not only focus on process improvement, but also on offering products and services, value chain processes and organizational structure changes (KIRON et al. 2013). According to Kleindorfer et al. (2005), the management of sustainable operations will contribute to make the companies more adaptable, agile and aligned with the dimensions of sustainability.

Some researchers point out the contribution of IMS for sustainability. According to López-Fresno (2010), Integrated Management Systems (IMSs) can provide several benefits related to decision making, communication and resource use (e.g. ISO 9001, ISO 14001, OHSAS 18001 and ISO 26000). Jørgensen et al. (2006) assert that if integration is seen as strategic, it will bring better competitive advantages, as well as contribute to sustainable development. Other authors such as Rocha et al. (2007) and Jørgensen (2008) also address the contribution of IMSs to sustainable development. According to Asif et al. (2011), using Integrated Management Systems (IMSs) enables sustainability in the main business processes. The integrated application of standards focused on quality (ISO 9001), the environment (ISO 14001), social responsibility (ISO 26000) and health and safety (OHSAS 18001) lead to major contributions concerning the development of more sustainable companies.

Another important aspect of changing to more sustainable business models is organizational structure. The functional management approach tends to isolate areas of knowledge in departments, making it more difficult to disseminate a systemic vision, which is a fundamental aspect for sustainability. In contrast to this approach, a Business Process Management (BPM) focuses on implementing the horizontal management of the organization through business processes (SILVA et al., 2012). 
According to ABPMP (2009), BPM is a disciplined approach to identify, design, execute, document, measure, monitor, control and improve business processes. It aims to meet an organization's strategic goals with customer focus. BPM can be understood as a method that complements Business Process Reengineering (BPR) and Total Quality Management (TQM) as it seeks to improve operational and managerial processes based on the objectives and goals established in strategic planning (GARVIN, 1995; TRKMAN, 2010).

Considering that both IMS and BPM contributes to performance improvement in sustainability dimensions, this paper aims to present a proposal of a roadmap (a step-by- step guide that helps reach a certain goal) for sustainability in operations based on principles and practices of integrated management systems and business process management. The research question behind this proposal is "what are the knowledge and good principles and practices already publicized in the literature relating IMS and BPM and how to consolidate them into a roadmap to improve the maturity of BPM and IMS with focus on operations sustainability?" The proposal is the result of a three-year project. A systematic bibliographic review was conducted in order to identify IMS and BPM principles, practices and techniques. Based on the literature search findings, the roadmap was designed. A field research with specialists was carried out so as to review and evaluate the value of the roadmap.

At a time when sustainability is increasingly required, studying this theme and looking for ways to provide a guide that supports the achievement of sustainability based on available and consolidated principles and practices is one of the main contributions of this article. Another contribution is the result of the systematic literature review developed during the project.

\section{THEORETICAL FOUNDATION}

\subsection{Integrated Management Systems (IMSs)}

A management system is a set of procedures that an organization adopts to reach its objectives (ISO, 2015a). An IMS can be defined as a process of joining different management systems inside a single system (BECKMERHAGEN et al. 2003).

Karapetrovic and Willborn (1998) present three strategies for implementing an IMS: 1) Organizations can implement a quality management system and then an environmental 183 
management system; 2) they can implement the environmental management system first and then the quality management system or 3 ) use both systems simultaneously.

There are many management systems and the most used worldwide are: ISO 9001 (Quality Management System), ISO 14001 (Environmental Management System), OHSAS 18001 (Occupational Health and Safety Management System), ISO 26000 (social responsibility), SA 8000 (Social Accountability 8000), AA 1000 (Assurance Standard 1000), and others.

The ISO 26000 provides guidelines for social responsibility practices in organizations. It provides guidance on the principles of social responsibility, considering stakeholder engagement, human rights, environment, work practices, legal operating practices, and others (ISO, 2010). The Social Accountability 8000 (SA 8000) also points out social responsibility requirements for organizations to develop, maintain and enforce policies and procedures related to the subject. The focus of this norm is related to working conditions (Social Accountability International, 2014). The AA1000 (Assurance Standard 1000) is a standard for social responsibility, but focusing on the inclusion of stakeholders and ensuring the quality of accounting, auditing and ethical social reporting (ACCOUNTABILITY, 2015).

The ISO 9001 and ISO 14001 were updated in 2015. These versions were considered in this study. These two standards follow the same high level structure, which reinforces the commonalities of both standards. In addition to that, there several other similarities: stakeholders should be considered and engaged; top management must take responsibility for the environmental or quality management system, ensure competencies, awareness and communication, evaluate performance and continuously improve the system. In ISO 9001 risks and opportunities must be identified and considered (FONSECA; DOMINGUES, 2017). ISO 14001: 2015 brings the need to consider the life cycle perspective as a novelty (FONSECA, 2015). However, although there are many commonalities, there are important differences between these two management systems. For instance, while clause 8 of ISO9001 presents the requirements to minimize the chance of non-conformity throughout product realization, clause 8 of ISO14001 deals with requirements to minimize environmental impacts. 
There has been an increase in the number of certifications. From 2004 to 2014, ISO 9001 certifications went from 660,132 to $1,138,155$ and ISO 14001 certifications increased from 90,554 to 324,148 (ISO, 2015c).

The OSHAS 18001 standard presents requirements for the implementation of an occupational health and safety management system (BRITISH STANDARDS INSTITUTION, 2007).

Mežinska et al. (2013) state that the requirements of ISO 9001, ISO 14001 and OHSAS 18001 can be used together in an IMS focusing on social responsibility, but the IMS alone does not ensure corporate social responsibility. These standards show clear benefits on certain issues, such as efficiency, employees, systematization, customers and other stakeholders, which indicates that, in general terms, certified firms improve people, operational and stakeholder performance (TARÍ et al., 2012).

Jørgensen (2008) claims that management systems of quality, environmental and occupational safety contribute to sustainable management. According to Fresner and Engelhardt (2004), the basis for sustainable development can be developed by small steps, starting with implementing Cleaner Production, followed by an IMS and optimizing relations in the supply chain.

According to Witjes et al. (2017), the necessity of understanding the use of integrated management systems for the success of corporate sustainability in different enterprises is confirmed, as it was observed that the importance of certifying business management systems with the use of standards increased as companies grew towards the sustainability stage.

Rebelo et al. (2016) states that the adoption of an IMS is nowadays a strategic decision of relevant importance for the competitiveness and sustainability of organizations. He points out that the integration of several management systems standards versus individual management systems may bring benefits such as the elimination of conflicts between individual MSs and the creation of added value for business through the elimination of several types of organizational waste.

The main benefits of integration shown by various studies are: a reduction in audits, a reduction in bureaucracy, a decrease in documentation, cost reduction, improvement in communication, improvement in making decisions, promoting better alignment with strategic 
planning, a holistic view, better involvement of employees, resolving conflicts, among others (POLTRONIERI et al., 2017). But, it is very difficult to manage different management systems on a separated way, which makes very important the integration between them. IMS became necessary inside the organizations as ISO made it easier to integrate different standards, which is made by a continuous learning process through cross-functional groups, teamwork and knowledge management. In addition, the integration of MSs promotes sustainable management (HOLM et al., 2015).

\subsection{Business process management (BPM)}

Business Process Management can be understood as a management approach to achieving strategic objectives as outlined in an organization's strategic plan, which means going from strategic goals to individual process goals, doing it through the improvement and control of business processes (JESTON; NELIS, 2006).

According to ABPMP (2009), BPM is a disciplined approach to identify, design, execute, document, measure, monitor, control and improve business processes and it aims to meet an organization's strategic goals with customer focus. BPM can be understood as a method that complements Business Process Reengineering (BPR) and Total Quality Management (TQM) as it seeks to improve operational and managerial processes based on the objectives and goals established in strategic planning (GARVIN, 1995 and TRKMAN, 2010).

BPM originates from two approaches: business process reengineering, which was an approach introduced by Michael Hammer (Hammer, 1990); and total quality management. Both approaches focus on business process improvement in different ways: business process reengineering is a radical approach for change, while total quality management prioritizes incremental changes. BPM can be seen as a balanced approach, which combines BPR and TQM to improve and manage business processes (GARVIN, 1995).

Kohlbacher (2010) highlights that the main benefits of BPM include: increasing operation speed, enhancing customer satisfaction, reducing operational costs, improving financial performance and improving the quality of products and services. Neubauer (2009) and McCormack et al. (2009) also mentioned that BPM enables companies to achieve quick 
organizational adaptation by providing the development and continuous improvement of organizations.

Recently, the ISO standards for quality and environmental management have been updated and now explicitly mention BPM as an important part of management systems. According to ISO 9001 and 14001, quality and environmental management systems have to be integrated into key business processes in order to improve quality and environmental performance. Some examples of key business processes aiming at quality and environmental performance include: purchasing and supply chain management, manufacturing and product development.

During the SLR, similar principles were identified in the literature on IMSs and BPM (i.e., involvement and commitment, leadership, continuous improvement, business process view, systemic thinking) (see Appendices A and B). This fact makes it easier to achieve greater maturity in both areas since the same principle contributes to increasing the maturity of both BPM and IMSs. The concept of maturity will be explained shortly. Furthermore, BPM allow organizations to overcome several barriers among its departments (SILVA et al. 2012) which can support IMSs.

\subsection{Maturity of IMSs and BPM}

According to PMI (2003), a maturity model is a structure formed of parts that define the maturity in a specific area. For Maier et al. (2012), maturity models help organizations to understand where they are and how much is missing to reach the best practices.

Maturity models are widely used and specific models can be found for quality management, product development, innovation, software development, among other areas. According to a systematic review carried out by Wendler (2012), although there are maturity models for various areas, the largest concentration is in the areas of software development and software engineering.

The Crosby's Quality Management Maturity Grid is considered the first maturity model. According to Crosby (1986), the score has 5 levels of maturity designated as (Table 1): uncertainty, awakening, enlightenment, wisdom and certainty. In total, there are 6 items 
evaluated. These items are: Management understanding and attitude; Quality organization status; Problem handling; Cost of quality as \% of sales; Quality improvement actions; and Summary of company quality posture. To use the tool, just read each row and note which columns best fit the reality of the organization being evaluated. Ideally, different people within the same organization should complete this evaluation tool to assess how different the perspectives are.

Table 1- Part of Crosby’s Quality Management Maturity Grid

\begin{tabular}{|c|c|c|c|c|c|}
\hline & Uncertainty & Awakening & Enlightenment & Wisdom & Certainty \\
\hline $\begin{array}{l}\text { Problem } \\
\text { handling }\end{array}$ & $\begin{array}{l}\text { Problems are } \\
\text { fought as they } \\
\text { occur, no } \\
\text { resolution, } \\
\text { inadequate } \\
\text { definition, lots of } \\
\text { yelling and } \\
\text { accusations. }\end{array}$ & $\begin{array}{l}\text { Teams are set up } \\
\text { to attack major } \\
\text { problems. Long- } \\
\text { range solutions } \\
\text { are solicited. }\end{array}$ & $\begin{array}{l}\text { Corrective action } \\
\text { communication } \\
\text { established. } \\
\text { Problems are faced } \\
\text { openly and resolved } \\
\text { in an orderly way. }\end{array}$ & $\begin{array}{l}\text { Problems are } \\
\text { identified early in } \\
\text { their } \\
\text { development. All } \\
\text { functions are } \\
\text { open to } \\
\text { suggestion and } \\
\text { improvement. }\end{array}$ & $\begin{array}{l}\text { Except in the } \\
\text { most unusual } \\
\text { cases, problems } \\
\text { are prevented. }\end{array}$ \\
\hline
\end{tabular}

Source: adapted from CROSBY, 1986.

One of the best known models, the CMM - Capability Maturity Model, was inspired by Crosby's Quality Management Maturity Grid. The CMM was elaborated by the Software Engineering Institute (SEI) - Carnegie Mellon, and this institute developed several other models after the CMM, among them the CMMI - Capability Maturity Model Integration (Bruin et al., 2005). In the area of management systems, there is a model to evaluate quality management systems and it was published in ISO9004.

Maturity models for IMSs and BPM were identified in the literature: for IMSs, Domingues et al. (2016) and Poltronieri et al. (2017); for BPM, OMG (2008), Jeston and Nelis (2006), Skrinjar and Trkman (2013) and Rohloff (2011). All maturity models were used to build the Maturity Assessment Tool (see Appendices C and D).

\section{METHODOLOGICAL PROCEDURES}


The methodology consisted firstly of a bibliographical review that aimed to identify principles, practices and techniques of IMS and BPM. This search was of great importance in the subsequent process of building the roadmap and was divided into two stages: an exploratory review and a systematic literature review (SLR). Five articles about IMSs and nine articles about BPM were read with the objective of conducting an exploratory review that served as the basis developing strings used in the systematic review, as well as for the initial survey of principles, practices and techniques.

An SLR on IMSs and BPM was conducted according to Conforto et al. (2011). The SLR helps to achieve a higher level of reliability in the review and the proposal presented by them was made with the intention of adapting it to the area of operations management. The databases used for the search were the Web of Science and Scopus. The search strings were developed using a previous literature review about IMSs and BPM, as mentioned below (Table 2).

Table 2 - Search string

\begin{tabular}{l|l} 
Area & String \\
\hline IMS & $\begin{array}{l}\text { TS=((ISO OR OHSAS OR EMAS OR SA8000 OR BS7750 OR BS5750 OR BS8800 OR NBR } 16001 \\
\text { OR NBR18801 OR AS/NZS 4801) AND ("integrated management system" OR "integrated } \\
\text { systems" NEAR/3 integrat*) OR ("standardized management system" OR "standardized } \\
\text { management systems" NEAR/3 integrat*) OR ("management system standards" NEAR/3 integrat*)) }\end{array}$ \\
\hline BPM & $\begin{array}{l}\text { TS=(("business process management" OR "process orientation") NOT ("software engineering" OR } \\
\text { "data mining" OR "web services" OR "information technology")) }\end{array}$
\end{tabular}

Source: Authors.

The string presented was used in the Web of Science and adapted to Scopus. 
The search string was applied to titles, abstract and keyword in both databases. To select an article, it had to contain principles, practices or techniques concerning IMSs or BPM. Two undergraduate and three graduate students participated in this extraction process.

The following definitions were adopted in this research:

- Principle: management principles can be understood as fundamental rules which are accepted as the basis for management (SOUSA; VOSS, 2002; GAMBI, 2014).

- Practice: management practices are standard and recurrent execution of techniques based on principles (SOUSA; VOSS, 2002; GAMBI, 2014).

- Technique: methods (way of doing) and/or tools (intellectual mechanism) that support the management process (SOUSA; VOSS, 2002; GAMBI, 2014).

A two-step procedure was adopted to review and identify articles which fit the inclusion criteria: (1) select articles by reading articles title, abstract and keywords, (2) select articles by reading the full article. Figure 1 shows the results of each review.

Figure 1 - Results of the SLR
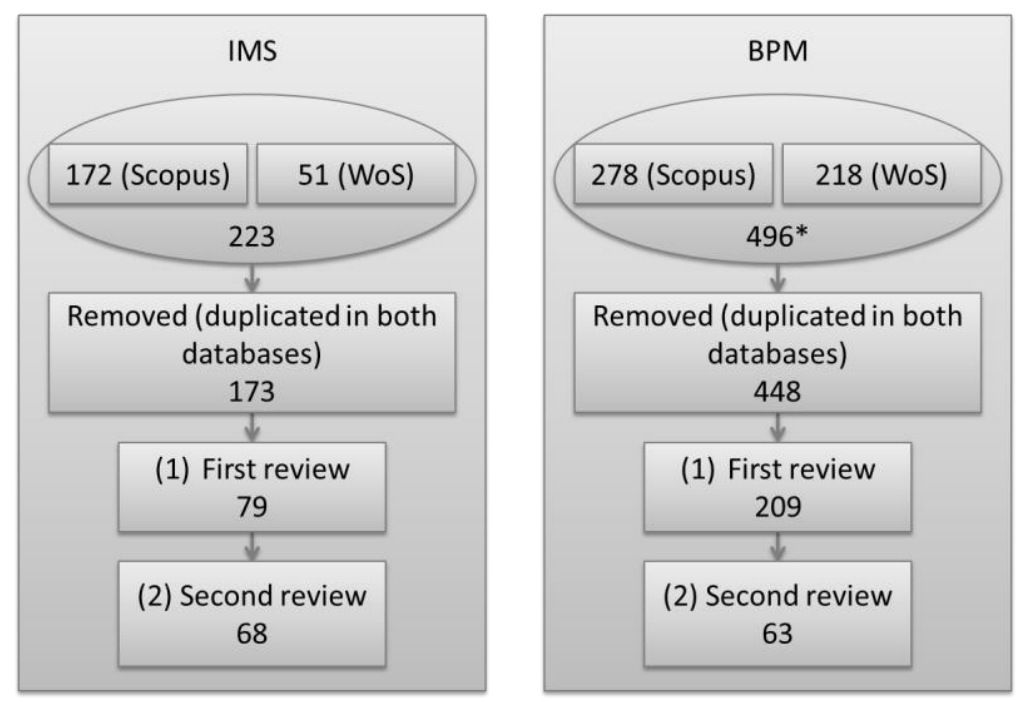

Source: Authors.

* For BPM, a previous refinement was made at the time of the search, accepting only articles from the following research areas: engineering; business economics; operations research management; environmental sciences; public administration; social sciences; and health care sciences services. 
The IMS and BPM principles, practices and techniques were extracted from the articles and added to a list. In the articles, it was identified that the same principles, practices and techniques had different nomenclatures. These nomenclatures were grouped and later standardized. This standardization was validated by 3 academic experts. The specialists hold a doctor degree and develop researches in the area.

The principles and practices were used to develop the matrix (see Appendices A and B). For BPM, 8 principles and 24 practices were found in the literature review. Note that this classification can make it easier to understand and apply BPM, as there is a misunderstanding about the definition of BPM in the related literature (JESTON; NELIS, 2006). For IMSs, 7 principles and 10 practices were identified. IMS and BPM principles and practices were detailed, based on articles, books and on the researchers' own experience, resulting in a glossary. The glossary was designed to help the practitioners in the organizations that have questions regarding the definitions of IMS and BPM principles and practices. The task of preparing the glossary was divided between three undergraduate students and supervised by three graduate students who were responsible for searching the definitions of each principle and practice as well as benefits, barriers, techniques and bibliographic references.

The next step taken when developing the roadmap was the search for IMS and BPM maturity models. The selected models were used to construct the maturity elements of IMSs and BPM (see Appendices C and D). Then, a tool was developed for maturity evaluation based on the maturity elements. For the evaluation, each question had to be answered on a 5point scale, which varied from totally disagree (1) to totally agree (5). The instrument that evaluated maturity in IMSs had 19 questions (Poltronieri et al., 2016) and was made based on Poltronieri (2017), Domingues (2013), Bernardo (2009) and a reviewed version of the ISO 9001:2015 (ISO, 2015b). The BPM evaluation instrument has 29 questions and was developed based on studies from OMG (2008), Jeston and Nelis, (2006), Rohloff (2011) and Skrinjar and Trkman (2013).

Next the matrix was developed for both IMSs and BPM, which relates maturity elements to principles and practices. Three academic experts were consulted to verify clarity and completeness of the matrix and sustainability principles were inserted into the IMS matrix 191 
based on Ferreira and Gerolamo (2016). The criteria selection of academic experts was background and experience in the IMS and BPM area.

The binary scale was used to relate principles, practices and maturity elements. In other words, this classification indicates the potential of a principle or practice to enhance the maturity level of IMS or BPM elements. Afterwards, the roadmap was developed by researchers. The roadmap was based on PDCA (Plan-Do-Check-Act) cycle.

Next, the roadmap was submitted to a field research. This procedure included an evaluation by experts on IMSs and BPM from research and professional areas. The field research method is shown in Figure 2.

Figure 2 - The field research steps

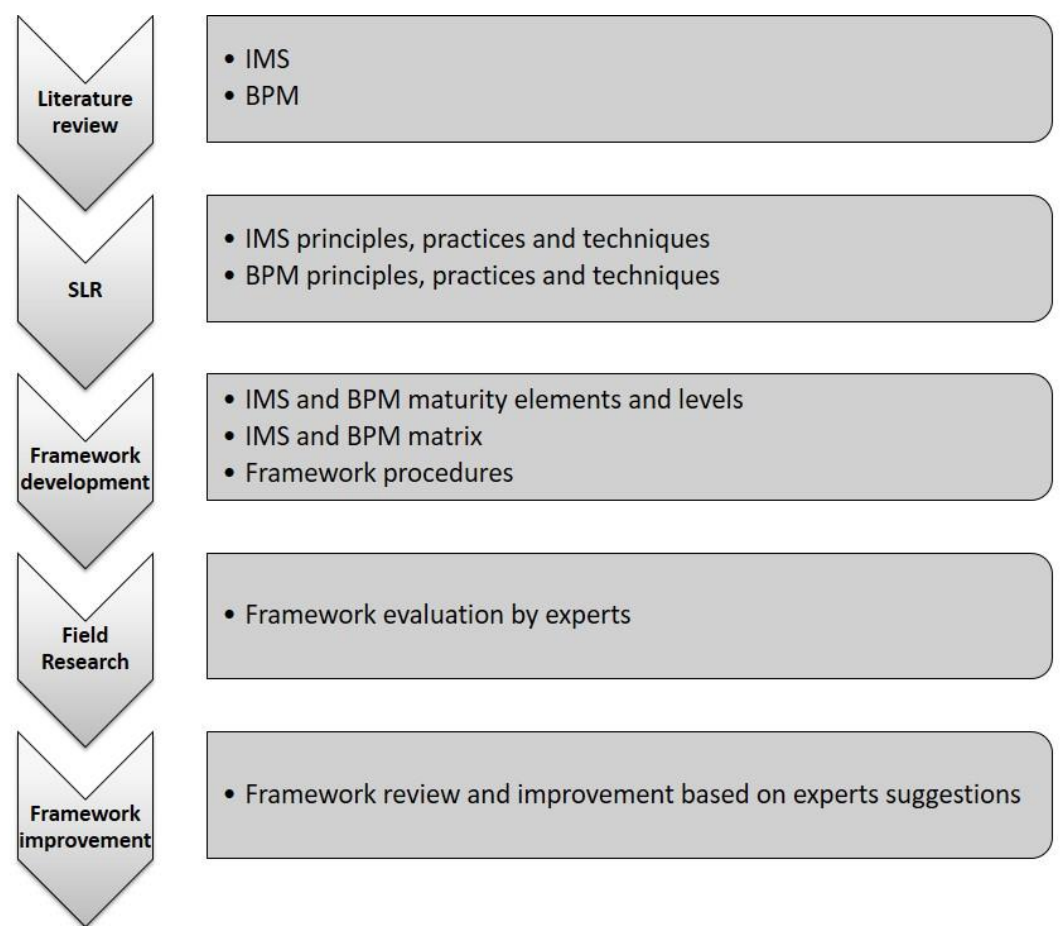

Source: Authors.

First, a search of IMS and BPM experts was conducted in some Brazilian companies and universities. The selection of the specialists was based on the following criteria. For IMS specialists, having a university degree, training in ISO 14001 and ISO 9001 standards and at least two years of practical experience in the field. For the BPM specialists, also having a 
university degree and be member of the Association of Business Process Management Professional (ABPMP). Moreover, prior to the evaluation by the specialists, as a pilot test, the roadmap was evaluated by 7 students (undergraduate, master's and doctoral students).

The research was conducted using contacts with acquaintances and through the professional network: Linkedin. In total, 27 specialists in IMS and 26 in BPM were contacted by e-mail. From the 27 IMS specialists, only 9 accepted to participate in the validation, but 4 actually responded to the survey. From 26 BPM specialists, 11 accepted but in fact only 5 answered. The validation was sent by Google Forms and e-mail.

In order to evaluate the roadmap, four criteria were adopted in the field research, adapted from Oiko (2013): clarity, completeness, usability and cohesion. In addition, questionnaires were designed to identify the strengths and weaknesses of the roadmap. The process of analyzing the answers of the specialists was qualitative since there wasn't enough data for quantitative analysis. The results from the field research were analyzed and used to review the roadmap.

\section{RESULTS}

\subsection{Theoretical roadmap}

In order to improve maturity elements towards a sustainable business, companies should focus on IMS and BPM principles and practices (see Figure 3). In this research, principles and practices on IMS and BPM were identified using an SLR and can be seen as the basis for improvements and integration in IMSs and BPM (see Appendices A and B). The IMS and BPM elements were extracted from maturity models found in the literature. Afterwards, the Maturity Assessment Tool to assess IMS and BPM maturity was developed. The objective was to achieve sustainability.

Figure 3 - Framework for BPM and IMS maturity levels, principles and practices. 


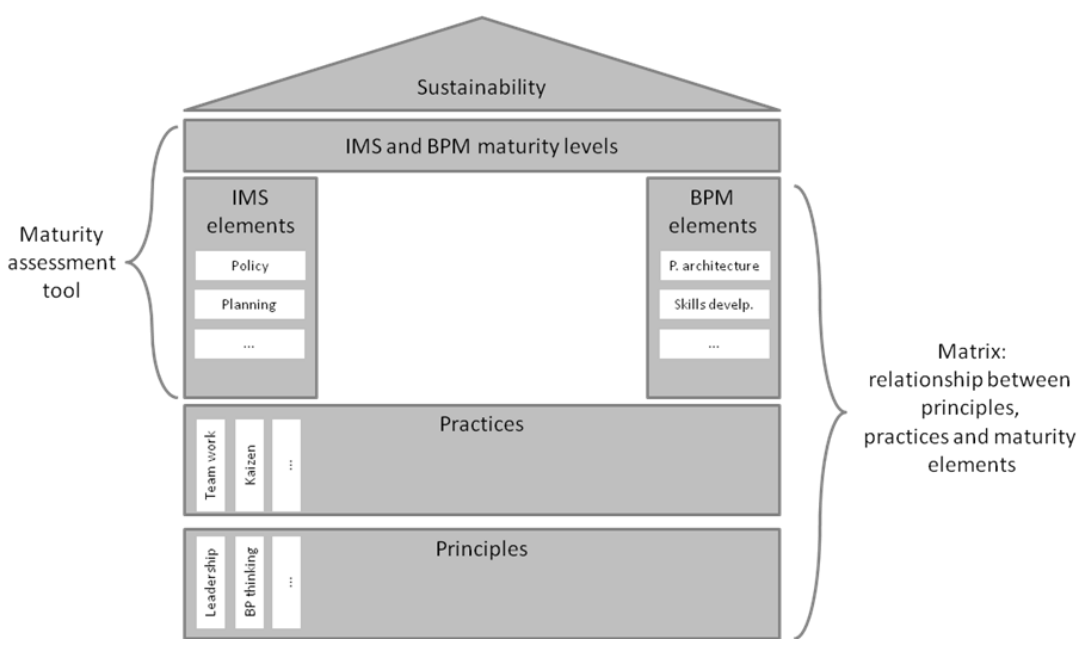

Source: Authors.

Based on Figure 3, the theoretical roadmap was developed and reviewed through field research. Although the literature review has identified techniques as well, the proposed roadmap considers only principles and practices since the choice techniques is very much case dependent. Considering the results of the field research, the roadmap presented in topic 4 was developed. The theoretical roadmap is not presented here and some changes were made in the theoretical version, resulting in the final roadmap presented in this paper. These modifications can be seen in the next topic.

\subsection{Field research results}

According to the experts' answers, the overall evaluation of the model was positive. The experts agreed that the roadmap includes the main principles of IMSs and BPM and the tool considers all the aspects of each element. However, it was pointed out that the model does not focus on Information Technology (IT) for BPM, which is not foreseen in the scope of the project. All the tools developed to help the roadmap ranked high in clarity, usability and content. Similarly, the phases of the roadmap were also given good scores in the criteria above and in continuity as well, which evaluates if the phases are presented in a logical way.

Additionally, the experts were asked to highlight the strengths and weaknesses of the proposed model. The roadmap was considered logical, well-structured and as having good theoretical content. However, the model requires the user's previous knowledge in BPM and 
IMSs in order to successfully evaluate the organization's maturity level and hereafter develop the roadmap.

\subsection{Proposal of the roadmap}

Figure 4 shows the developed roadmap which is based on the structure previously presented in the PDCA. The main purpose of this roadmap is to support IMS and the adoption of process management in order to promote business sustainability. This roadmap is designed for internal use only, which means that companies can use the roadmap based on their own maturity in IMSs and BPM, as well as their own practices.

Figure 4 - Proposal of a roadmap for sustainability in operations.

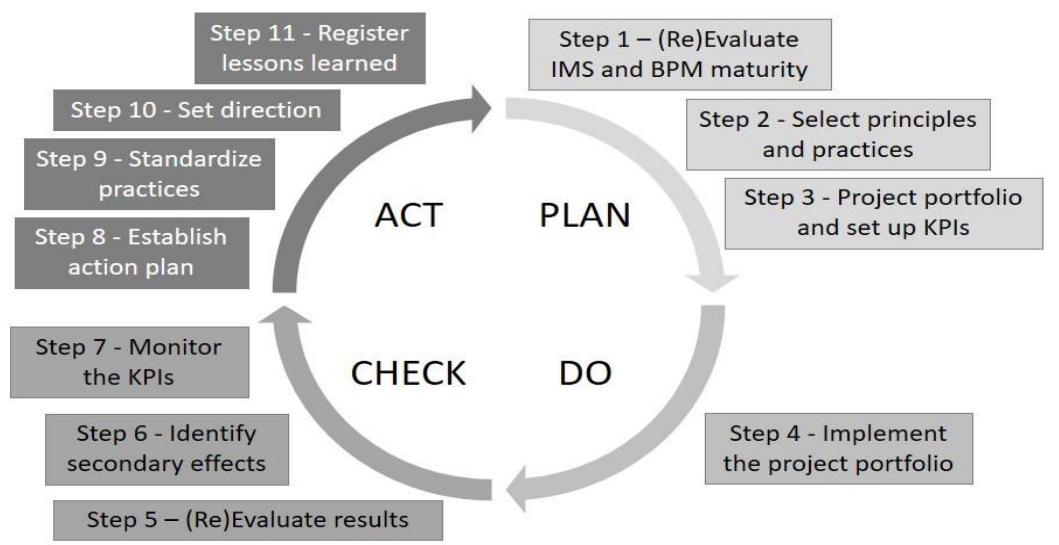

Source: Authors.

\subsubsection{Plan}

This phase has three steps: (re)evaluate IMS and BPM maturity, select the main IMS and BPM principles and practices and define the project portfolio. During this phase, companies are supposed to identify their maturity both in IMS and BPM, as well as what the specific elements are which require attention. Then, companies can identify and select principles and practices in IMS, BPM and sustainability which can contribute to improving the maturity of the elements. These principles and practices are explored in workshops in 
order to generate ideas, which are then compiled in projects. These projects are the basis for the roadmap. The following sub-sections present the 3 steps of the Plan phase.

\section{Step 1 - (Re)Evaluate IMS and BPM maturity}

The main purpose of the first step is to evaluate IMS and BPM maturity in order to provide a clearer picture about where the company is concerning IMS and BPM practices. In this step, the company has to use the Maturity Assessment Tool regarding IMS and BPM which must be answered by experts. It is recommended that more than one expert on each topic participate, and if possible, experts should be selected according to their company background.

The Maturity Assessment Tool (see Appendices C and D) was developed through an in-depth literature review on IMSs and BPM. The IMS tool has 19 elements with 19 questions and it was published by Poltronieri et al. (2016). The BPM tool has 13 elements including 29 questions and was developed based on four studies: OMG (2008), Rohloff (2011), Skrinjar and Trkman (2013), and Jeston and Nelis (2006). The most recurrent and key elements were identified and grouped into 13 BPM elements, following the methodology adopted by constructing the IMS tool.

The experts must answer the Maturity Assessment Tool based on their knowledge. For each question, they must choose the agreement level in a 5-point scale, which varies from (1) totally disagree to (5) totally agree. If more than one expert participates in the maturity evaluation, the final score must be calculated through the average responses. These results will identify the weakest elements in IMSs and BPM which will require attention in the following step.

\section{Step 2 - Select the main IMS and BPM principles and practices}

In this step, the company has to select the main IMS and BPM principles and practices to address the weakest elements identified in the previous step. The matrices of IMS and BPM principles and practices were developed using an SLR and analysis by experts. By using these matrices, companies can identify principles and practices that can improve the maturity of IMS and BPM elements. 
Each matrix links principles and practices with maturity elements on a scale of 3 points: weak, medium and strong potential of improvement. This relationship can be used to prioritize principles and practices, since the company has to select few principles and practices to develop improvement projects and define the project portfolio in the next step. Other criteria include: potential of improvement across IMS and BPM elements; number of relationships with maturity elements; strength of each relationship.

The principles and practices can be prioritized by users using the Maturity Assessment Tool that analyzes the elements of maturity of the BPM and IMS. Employees who answer this tool should have knowledge on the issues addressed. The results will show which elements need to be attacked. After this diagnosis, users will be able to identify which principles and practices are common between IMS and BPM and prioritize for a greater integration between the BPM and IMS.

The roadmap also includes a glossary which presents a description of each principle and practice of the IMS and BPM. In depth-research about the selection is recommended before the next step as this is strongly related to the success of implementing practices and its contribution to enhancing IMS and BPM maturity.

\section{Step 3 - Project portfolio}

The purpose of this step is to define the projects and action plans to improve the maturity of IMS and BPM. In this step, companies should develop: an IMS project, a BPM project and a final project including IMS and BPM. In this step, the company will need to define which Key Performance Indicators (KPIs) they will use and which they will select to evaluate the roadmap.

During step 3, a team of experts identifies and develops attributes for projects and their relationships with each other (KOSTOFF; SCHALLER, 2001). For this, experts should perform iterative workshops whose purposes are to capture and discuss perspectives, explore opportunities, build a consensus and develop a roadmap to implement the projects.

At least three workshops must be carried out: the IMS and sustainability workshop, the BPM workshop and the integration workshop. The first workshop is about IMS and sustainability principles and practices, while the second is about BPM principles and 
practices. To select the experts who will participate in the workshop, they will be used as criterion to work in one of the respective areas, in the case of BPM or IMS, in their organization. Both workshops have the same structure: introduction about selected principles and practices; developing improvement projects for each principle and practice; identifying relationships between projects and maturity elements; evaluating the proposed projects; constructing the project portfolio.

The third workshop presents some differences. First, the input is the project portfolio developed in the previous workshops. Second, the team of experts should focus on integrating projects into the final project portfolio, which means merging similar projects and adjusting projects in order to optimize efforts and results. The final project portfolio must be validated before the next phase.

\subsubsection{Do}

In this phase, the company has to implement the project portfolio through project management practices. The proposed project portfolio was built based on PMBOK (Project Management Body of Knowledge) from the Project Management Institute (PMI, 2013), which is a complete framework for project management and the company should adapt to its needs case-by-case.

In general, each project has five stages: initiation, planning, executing monitoring and controlling, and closing. Figure 5 shows a short description of each stage. During this phase, the main stakeholders related to business can be identified and engaged according accountability standards AA1000 SES, which define a process and tools for stakeholders engagement (ACCOUNTABILITY, 2015). 
Figure 5 - Implement the project portfolio.

\begin{tabular}{|c|c|c|c|c|}
\hline Initiation $\rightarrow$ & Planning & Executing & $\begin{array}{l}\text { Monitoring and } \\
\text { Controlling }\end{array}$ & Closing \\
\hline $\begin{array}{l}\text { Identify stakeholders } \\
\text { Develop project charter } \\
\text { - Objective } \\
\text { - Scope } \\
\text { - Resources }\end{array}$ & $\begin{array}{l}\text { Define scope } \\
\text { Specify actions } \\
\text { Develop project plan: } \\
\text { - Scope } \\
\text { - Timing } \\
\text { - Quality } \\
\text { - Communication } \\
\text { - Resources } \\
\text { - Acqu } \\
\text { - Costs } \\
\text { - Requirements } \\
\text { - Process improvement } \\
\text { - Stakeholders }\end{array}$ & $\begin{array}{l}\text { - Project execution } \\
\text { - Manage stakeholders } \\
\text { expectations } \\
\text { - Measure } \\
\text { performance } \\
\text { - Update project plan }\end{array}$ & $\begin{array}{l}\text { - Project follow up } \\
\text { - Monitoring and } \\
\text { controlling } \\
\text { - Analyze results } \\
\text { - Organize progress } \\
\text { - } \text { Change management } \\
\text { Register lessons learned }\end{array}$ & $\begin{array}{l}\text { - Integrate lessons learned } \\
\text { - Check activities and } \\
\text { requirements } \\
\text { - Confirm project closing } \\
\text { - Review activities and } \\
\text { deliverables } \\
\text { - Manage documents }\end{array}$ \\
\hline
\end{tabular}

Source: adapted from PMI 2013.

\subsubsection{Check}

The aim of this phase is to check the results of the project implementation. In general, 3 steps have to be followed by companies: (re)evaluate results, identify secondary effects and monitor the KPIs.

In order to (re)evaluate the results, the companies should analyze the main objective of each project and compare it against their deliverables. Companies should adopt follow-up reports and visual management. In this phase, companies also have to identify and create a list of secondary effects, which could be positive or negative. Based on this list, an action plan can be established for each secondary effect, especially the negative ones. Then, the KPIs selected to evaluate the project portfolio should be monitored.

\subsubsection{Act}

In this phase, companies have to select a decision about the next steps. Four steps should be executed in this phase: establish action plan, establish standard of new practices, set direction and register lessons learned.

Implementing each project will drive changes in the company's business processes. Based on the secondary effects listed in the previous phase, the company must define an 
action plan to address them. This could be done through business process improvement techniques (i.e. Ishikawa Diagrams, Theory of Constraints tools). The company also has to engage people in order to establish the standard of new practices, which means communicating and managing the new practices. The company has to make a decision about the next step, improving the IMS, BPM and sustainability maturity. Finally, lessons learned from each project should be reviewed and integrated. This can be useful to promote critical reviews and improvement.

\section{CONCLUSION}

The main objective of this study was to develop and evaluate the roadmap for IMSs focused on process management aiming at sustainability. The roadmap was developed through an extensive SLR to identify the principles, practices and techniques of IMSs and BPM. In addition, the following was developed: a tool to evaluate the maturity of IMSs and BPM from the main models of maturity in the literature; matrices to relate the potential contribution of principles and practices to increase the maturity of IMSs and BPM; and a glossary with a description of each principle and practice of IMSs and BPM found in the matrix.

The proposed roadmap is a generic model that can be used by any type of organization to increase the maturity of IMSs and their process management practices, aiming at sustainability. According to specialists, the roadmap requires some knowledge on IMS and BPM to be properly adopted. The roadmap provides a list of IMS and BPM principles and practices as well as a step-by-step approach to guide organizations to enhance their capability in IMSs and BPM. One of the benefits of this approach is to be flexible so that each organization defines which course is most appropriate based on its resource availability, strategy and priorities, and also the maturity level of the company's IMS and BPM.

Regarding consultation from experts (5 experts from BPM and 4 from IMSs), the theoretical roadmap was evaluated well and most of the notes were between "partially agree" and "strongly agree". The positive result of consulting with experts indicates that the roadmap is clear, it has relevant content and is consistent. When using the usability criterion, it was 
understood that evaluation through consultation with experts indicates the potential to be an easy-to-use tool.

A significant contribution of this research is the relationship between IMSs and BPM. It could be observed that the two topics are treated separately in the literature, although the new management system standards, published in 2015 (ISO 9001 and ISO 14001), explicitly mention the importance of integrating management systems into business processes. Thus, the roadmap developed can be used by organizations for this task, integrating management systems and the business processes.

Regarding the roadmap, it is an instrument that requires minimum knowledge of the two topics, which limits its application.

One of the limitations of the study was the reduced number of specialists who analyzed the roadmap. Therefore, it is suggested as a further work that this roadmap be validated by other experts, including people from different countries. Another limitation is the fact that the study has to advance on implementation issues posed by the proposed roadmap. In this sense, a further study should be carried out to address this point.

Finally, future work for this project includes: conducting case studies to evaluate the usability criteria of the roadmap, as well as improving it; developing a maturity instrument for sustainability; analyzing and detailing phases 2, 3 and 4 of the roadmap; defining the minimum knowledge level in IMSs and BPM to use the roadmap.

\section{Acknowledgements}

We thank the Coordination of Superior Level Staff Improvement for their assistance.

\section{References}

ABPMP (2009). Guia para o Gerenciamento de Processos de Negócio - Corpo Comum de Conhecimento (BPM CBOK).

ACCOUNTABILITY. AA1000 Stakeholder engagement standard. London: Institute of Social and Ethical AccountAbility.2015. 
ASIF, M; SEARCY, C; ZUTSHI, A; AHMAD, N. An integrated management systems approach to corporate sustainability. European Business Review, v. 23, n.4, p. 353-367, 2011.

BECKMERHAGEN, I. A; BERG, H. P; KARAPETROVIC, S. V; WILLBORN, W. O. Integration of management systems: focus on safety in the nuclear industry. International Journal of Quality \& Reliability Management, v. 20, n. 2, p. 210-228, 2003.

BERNARDO, M; CASADESUS, M; KARAPETROVIC, S; HERAS, I. How integrated are environmental, quality and other standardized management systems? An empirical study. Journal of Cleaner Production, v. 17, n. 8, p. 742-750, 2009.

BRITISH STANDARDS INSTITUTION. OHSAS 18001:2007. 2nd ed. London: OHSAS Project Group, 2007.

BRUIN, T; FREEZE, R; KAULKARNI, U; ROSEMANN, M. Understanding the Main Phases of Developing a Maturity Assessment Model. Australasian Conference on Information Systems, p. 8-19, 2005.

CONFORTO, E. C, AMARAL, D. C; SILVA, S. L. Roteiro para revisão bibliográfica sistemática: aplicação no desenvolvimento de produtos e gerenciamento de projetos. In: CONGRESSO BRASILEIRO DE GESTÃO DE DESENVOLVIMENTO DE PRODUTO, $\mathrm{n}$. 8, 2011. Anais... Sep 12-14; Porto Alegre, 2011.

CROSBY, P. B. Qualidade é Investimento: a arte de garantir a qualidade. Rio de Janeiro: José Olympio Editora, p. 327, 1986.

DOMINGUES, J. P. T. Sistemas de Gestão Integrados: Desenvolvimento de um modelo para avaliação do nível de maturidade. Dissertation, 147f. (mestrado) - Portugal: University of Minho, 2013.

DOMINGUES, P; SAMPAIO, P; AREZES, P. M. Integrated management systems assessment: a maturity model proposal. Journal of Cleaner Production, v. 124, p. 164-174, 2016.

ELKINGTON J. Cannibals with Forks: The Triple Bottom Line of the 21st Century. Stoney Creek: New Society Publishers, 1998.

FERREIRA, C. S; GEROLAMO, M. C. Analysis of the relationship between management system standards (ISO 9001, ISO 14001, NBR 16001 and OHSAS 18001) and corporate sustainability. Gestão e Produção, v. 24, p. 689-703, 2016.

FONSECA, L.ISO 14001:2015 - An improved tool for sustainability. Journal of Engineering and Management, v. 8, n.1, p. 7-50, 2015.

FONSECA, L; DOMINGUES, J. P. ISO 9001:2015 - Quality, Management, and Value. International Journal for Quality Research, v. 11, n. 1, p. 149-158, 2017.

FRESNER, J; ENGELHARDT, G. Experiences with integrated management systems for two small companies in Austria. Journal of Cleaner Production, v. 12, p. 623-63, 2004. 
GAMBI, L. N. A relação entre cultura organizacional e o uso de técnicas da qualidade e seu impacto no desempenho operacional. 2014. Disponível em: https://teses.usp.br/teses/disponiveis/18/18156/tde-16062014135954/publico/LillianNascimentoGambiDEFINITIVO.pdf. Acesso em 20 jun 2020.

GARVIN, D. Leveraging Processes for Strategic Advantage. Harvard Business Review, 1995.

HAMMER, M. Reengineering work: don't automate, obliterate. Harvard Business Review, v. 68, p.104-113, 1990.

HOLM, T; VUORISALO, T; SAMMALISTO, K. Integrated management systems for enhancing education for sustainable development in universities: a memetic approach. Journal of Cleaner Production, v.106, p. 155-163, 2015.

INTERNATIONAL ORGANIZATION FOR STANDARDIZATION. ISO 26000: Guidance on Social Responsibility, 1nd ed. Geneva: ISO Copyright Office. 2010.

ISO (2015a). Management system standard. Disponível em: http://www.iso.org/iso/home/standards/management-standards.htm. Acesso em 15 jun 2019.

ISO (2015b). ISO 9001:2015 - Quality management systems: Requirements. 5nd ed. Geneva: ISO Copyright Office.

ISO (2015c). The ISO Survey of Management System Standard Certifications - 2014. Disponível em: http://www.iso.org/iso/home/standards/certification/iso-survey.htm. Acesso em 15 jun 2019.

JESTON, J; NELIS, J. Business Process Management - Practical guidelines to successful implementation. Oxford: Elsevier, 2006.

JØRGENSEN, T. H; REMMEN, A; MELLADO, M. D. Integrated management systems three different levels of integration. Journal of Cleaner Production, v. 14, n. 8, p. 713-722, 2006.

JØRGENSEN, T. H. Towards more sustainable management systems: through life cycle management and integration. Journal of Cleaner Production, v. 16, n. 10, p. 1071-1080, 2008.

KARAPETROVIC, S; WILLBORN, W. Integration of quality and environmental management systems. The TQM Magazine, v. 10, n. 3, p. 204-213, 1998.

KLEINDORFER, P. R; SINGHAL, K; VAN WASSENHOVE, L. N. Sustainable Operations Management. Production and Operations Management, v. 14, p. 482-492, 2005.

KIRON, D; KRUSCHWITZ, N; HAANAES, K; REEVES, M; GOH, E. The innovation bottom line: how companies that see sustainability as both a necessity and an opportunity, and change their business models in response, are finding success. MIT Sloan Management Review, v. 54, p. 69-73, 2013. 
KIRON, D; UNRUH, G; KRUSCHWITZ, N; REEVES, M; RUBEL, H; MEYER ZUM FELDE, A. Corporate sustainability at a crossroads: progress toward our common future in uncertain times. MIT Sloan Management Review, 2017.

KOHLBACHER, M. The effects of process orientation: a literature review. Business Process Management Journal, v. 16, n. 1, p. 135-152, 2010.

KOSTOFF, R. N; SCHALLER, R. R. Science and technology roadmaps. IEEE Transactions on Engineering Management, v. 48, n. 2, p. 132-143, 2001.

LINNENLUECKE, M. K; GRIFFITHS, A. Corporate sustainability and organizational culture. Journal of World Business, v. 45, n. 4, p. 357-366, 2010.

LÓPEZ-FRESNO, P. Implementation of an integrated management system in an airline: a case study. The TQM Journal, v. 22, n. 6, p. 629-647, 2010.

MAIER, A. M; MOULTRIE, J; CLARKSON, P. J. Assessing Organizational Capabilities: Reviewing and Guiding the Development of Maturity Grids. IEEE Transactions on Engineering Management, v. 59, n. 1, p. 138-159, 2012.

MCCORMACK, K; DESCHOOLMEESTER, D; WILLEMS, J; WILLAERT, P; VAN DEN BERGH, J; STEMBERGER, M. I; SKRINJAR, R; TRKMAN, P; LADEIRA, M. B; VALADARES, D. E; OLIVEIRA, M. P; BOSILJ VUKSIC, V; VLAHOVIC, N. A global investigation of key turning points in business process maturity, Business Process Management Journal, v. 15, n. 5, p. 792-815, 2009.

MEŽINSKA, I; LAPINA, I; MAZAIS, J. Integrated management systems towards sustainable and socially responsible organisation. Total Quality Management \& Business Excellence, v. 26, n. 5-6, p. 1-13, 2013.

NEUBAUER, T. An empirical study about business process management. Business Process Management Journal, v. 15, n. 2, p. 166-83, 2009.

OIKO, O. T. Modelo dos processos de negócio para gerenciar a remanufatura. 2012. Tese (Doutorado em Processos e Gestão de Operações) - Escola de Engenharia de São Carlos, Universidade de São Paulo, São Carlos, 2012.

OMG. Business Process Maturity Model (BPMM) Version 1.0. 2008. Disponível: http://www.omg.org/spec/BPMM/1.0/PDF. Acesso em 16 dez 2016.

PMI. Organizational Project Management Maturity Model (OPM3), Pennsylvania: 179, 2003.

PMI. A guide to the Project Management Body of Knowledge, $5^{\text {th }} \mathrm{Ed}, 2013$..

POLTRONIERI, C. F; GEROLAMO, M. C; DIAS, T. C. M; CARPINETTI, L. C. R. Instrument for evaluating IMS and sustainable performance. In: INTERNATIONAL CONFERENCE ON QUALITY ENGINEERING AND MANAGEMENT, n.2, Anais...Jul 13-15; Guimarães, p 19-31, 2016.

POLTRONIERI, C. F; GEROLAMO, M. C; CARPINETTI, L. C. R. Um instrumento para a avaliação de sistemas de gestão integrados. Gestão \& Produção, v. 24, p. 638-652, 2017. 
REBELO, M. F; SANTOS, G; SILVA, R. Integration of management systems: towards a sustained success and development of organizations. Journal of Cleaner Production, v. 127, p. 96-111, 2016.

ROCHA, M; SEARCY, C; KARAPETROVIC, S. Integrating Sustainable Development into Existing Management Systems. Total Quality Management, v. 18, n. 1-2, p. 83-92, 2007.

ROHLOFF, M. Advances in business process management implementation based on a maturity assessment and best practice exchange. Information Systems E-Business management, v. 9, n. 3, p. 383-403, 2011.

SKRINJAR, R; TRKMAN, P. Increasing process orientation with business process management: Critical practices. International Journal of Information Management, v. 33, n. 1, p. 48-60, 2013.

SILVA, L. A; DAMIAN, I. P. M; PÁDUA, S. I. D. P. Process management tasks and barrier: functional to processes approach. Business Process Management Journal, v. 18, n. 5, p. 762-776, 2012.

SOUSA, R; VOSS, C. A. Quality management: universal re-visited: a reflective review and agenda for future research. Journal of Operations Management, v. 20, n. 1, p. 91-109, 2002.

SOCIAL ACCOUNTABILITY INTERNATIONAL. Guidance document for social accountability 8000. New York: SAI. 2014.

TARÍ, J. J; MOLINA-AZORÍN, J. F; HERAS, I. Benefits of the ISO 9001 and ISO 14001 standards: a literature review. Journal of Industrial Engineering and Management, v. 5, n. 2, p. 297-322, 2012.

TRKMAN, P. The critical success factors of business process management. International Journal of Information Management, v. 30, n. 2, p. 125-134, 2010.

WENDLER, R. The maturity of maturity model research: A systematic mapping study. Information and Software Technology, v. 54, n. 12, p. 1317-1339, 2012.

WITJES, S; VERMEULEN, W. J. V; Cramer, J. M. Exploring corporate sustainability integration into business activities. Experiences from 18 small and medium sized enterprises in the Netherlands, Journal of Cleaner Production, v. 153, p. 528-538, 2017. 
Appendix A. Matrix of principles and practices for BPM. Relationships are shown in gray and no relationships are shown in white.

Appendix B. Matrix of principles and practices for IMS and sustainability.

Relationships are shown in gray and no relationships are shown in white.

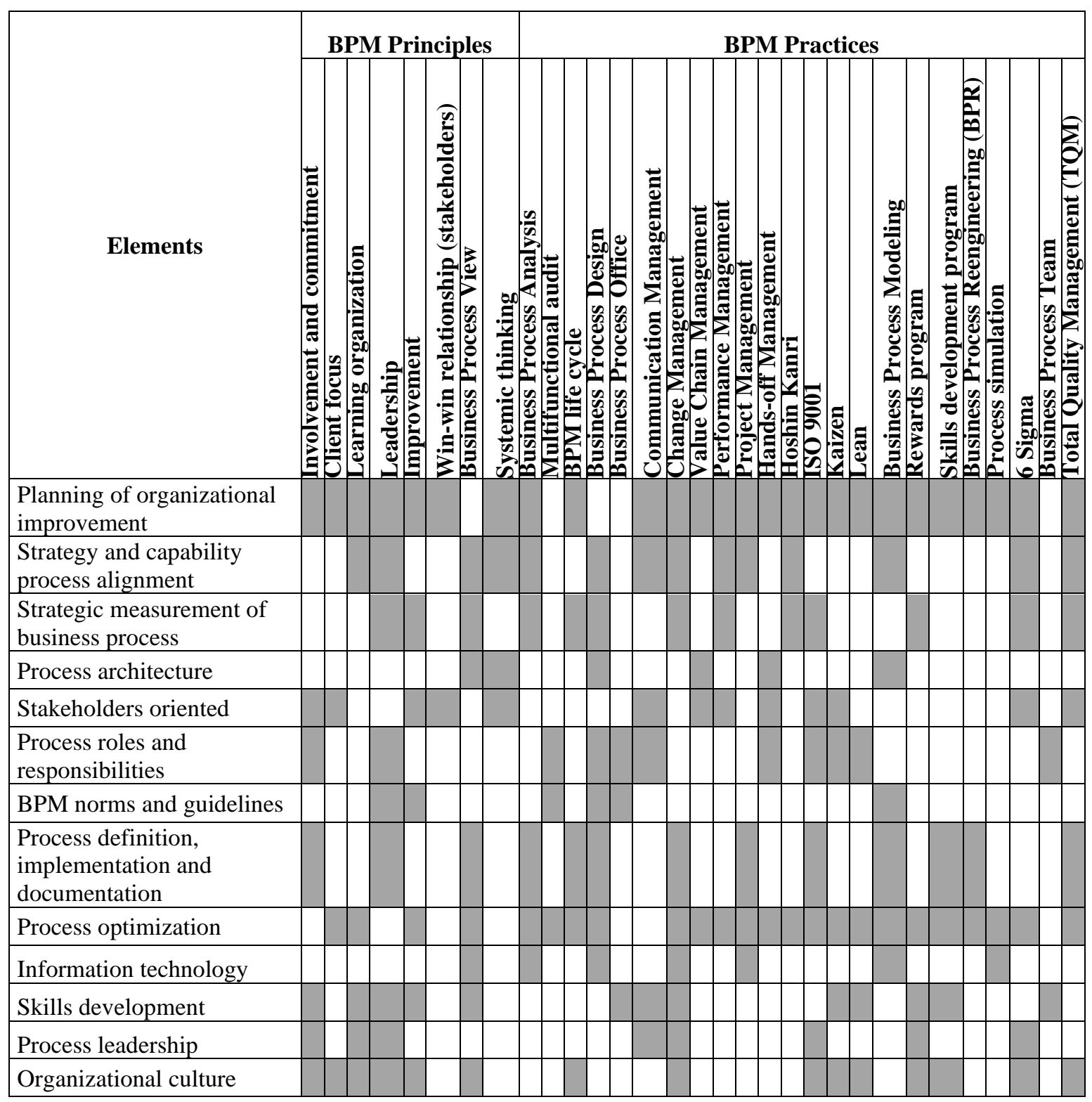




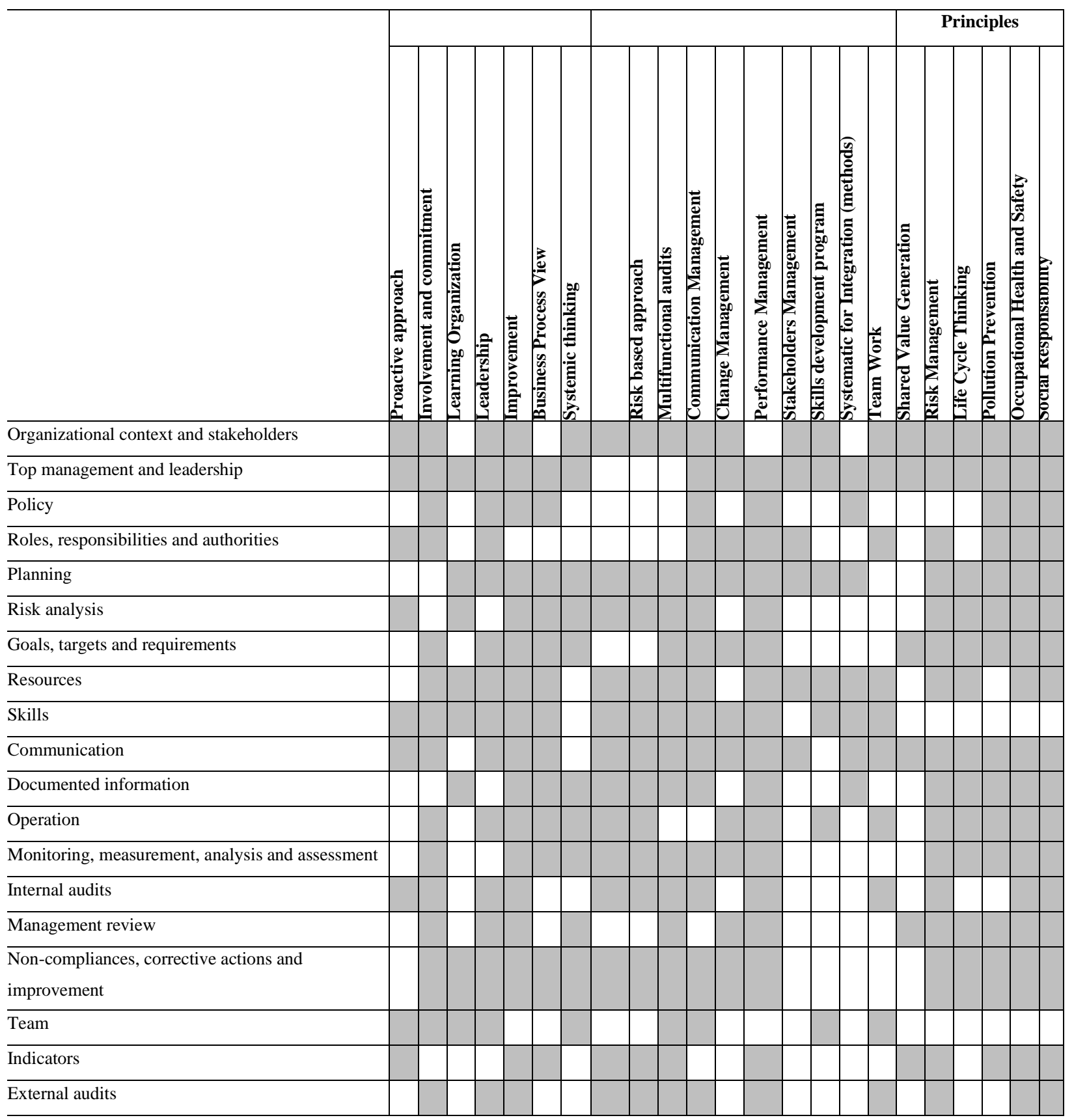


Appendix C. Maturity Assessment Tool for IMS

For each question, consider the following degrees of agreement 1-5, where 1 means "Strongly Disagree" and 5 means "Strongly Agree". If you are not sure of the answer or consider that it does not apply, check the alternative N/A.

\begin{tabular}{|c|c|c|}
\hline Element & Question & Agreement (1-5) \\
\hline $\begin{array}{l}\text { 1. Organizational } \\
\text { context and } \\
\text { stakeholders }\end{array}$ & $\begin{array}{l}\text { The evaluation of the organization's context } \\
\text { and stakeholders is made considering the } \\
\text { various management systems. }\end{array}$ & \\
\hline $\begin{array}{l}\text { 2. Top management and } \\
\text { leadership }\end{array}$ & $\begin{array}{l}\text { The leadership treats their different } \\
\text { management systems in a joint and unified } \\
\text { way. }\end{array}$ & \\
\hline 3. Policy & $\begin{array}{l}\text { There is a single policy that is integrated and } \\
\text { it is deployed in constantly revised indicators. }\end{array}$ & \\
\hline $\begin{array}{l}\text { 4. Roles, } \\
\text { responsibilities and } \\
\text { authorities }\end{array}$ & $\begin{array}{l}\text { Roles, responsibilities and authorities are } \\
\text { assigned and communicated considering } \\
\text { different management systems. }\end{array}$ & \\
\hline 5. Planning & $\begin{array}{l}\text { Planning is done jointly, resulting in a single } \\
\text { plan. }\end{array}$ & \\
\hline 6. Risk analysis & $\begin{array}{l}\text { The company performs risk analysis in an } \\
\text { integrated manner. }\end{array}$ & \\
\hline $\begin{array}{l}\text { 7. Goals, targets and } \\
\text { requirements }\end{array}$ & $\begin{array}{l}\text { Goals, targets and requirements are aligned } \\
\text { and integrated. }\end{array}$ & \\
\hline 8. Resources & $\begin{array}{l}\text { The resources (human, infrastructure, } \\
\text { financial) are distributed considering the } \\
\text { needs of the rules together. }\end{array}$ & \\
\hline 9. Skills & $\begin{array}{l}\text { The necessary skills are established } \\
\text { considering the demands of the different } \\
\text { management systems, providing training and }\end{array}$ & \\
\hline
\end{tabular}




\begin{tabular}{|c|c|}
\hline & other activities in a unified manner. \\
\hline 10. Communication & $\begin{array}{l}\text { There is a unique structure that takes care of } \\
\text { the whole communication process (internal } \\
\text { and external communication). }\end{array}$ \\
\hline $\begin{array}{l}\text { 11. Documented } \\
\text { information }\end{array}$ & $\begin{array}{l}\text { Creation, control and disclosure of all } \\
\text { documented information is treated in an } \\
\text { integrated manner, using a disclosure process } \\
\text { to ensure that everyone has access to it. }\end{array}$ \\
\hline 12. Operation & $\begin{array}{l}\text { Operational control is done jointly, } \\
\text { considering the different processes required } \\
\text { meeting the requirements of different } \\
\text { management systems. }\end{array}$ \\
\hline $\begin{array}{l}\text { 13. Monitoring, } \\
\text { measurement, analysis } \\
\text { and assessment }\end{array}$ & $\begin{array}{l}\text { The management system assessment } \\
\text { (monitoring, measurement and analysis) is } \\
\text { seen in an integrated way, and the indicators } \\
\text { are treated together and reviewed constantly. }\end{array}$ \\
\hline 14. Internal audits & $\begin{array}{l}\text { Internal audits are made considering the } \\
\text { requirements of the different management } \\
\text { systems. }\end{array}$ \\
\hline 15. Management review & $\begin{array}{l}\text { The management review is done jointly, } \\
\text { resulting in a single document. }\end{array}$ \\
\hline $\begin{array}{l}\text { 16. Non-compliances, } \\
\text { corrective actions and } \\
\text { improvement }\end{array}$ & $\begin{array}{l}\text { Treatment of non-compliances is done } \\
\text { considering the different management } \\
\text { systems. }\end{array}$ \\
\hline 17. Team & $\begin{array}{l}\text { There is a single organizational structure area } \\
\text { responsible for management systems. }\end{array}$ \\
\hline 18. Indicators & $\begin{array}{l}\text { Indicators are jointly selected and the results } \\
\text { are widely available, and they are constantly }\end{array}$ \\
\hline
\end{tabular}




\begin{tabular}{|l|l|l|}
\hline & revised. & \\
\hline 19. External audits & $\begin{array}{l}\text { External audits (the certifying body) are made } \\
\text { while considering the requirements of the } \\
\text { different management systems. }\end{array}$ & \\
\hline
\end{tabular}

Appendix D. Maturity Assessment Tool for BPM

For each question, consider the following degrees of agreement 1-5, where 1 means "Strongly Disagree" and 5 means "Strongly Agree". If you are not sure of the answer or consider that it does not apply, check the alternative N/A.

\begin{tabular}{|c|c|c|}
\hline Element & Question & Agreement (1-5) \\
\hline $\begin{array}{l}\text { 1. Planning of } \\
\text { organizational } \\
\text { improvement }\end{array}$ & $\begin{array}{l}\text { The business process improvement activities } \\
\text { are driven by strategic planning. }\end{array}$ & \\
\hline \multirow[t]{2}{*}{$\begin{array}{l}\text { 2. Strategy and } \\
\text { capability process } \\
\text { alignment }\end{array}$} & $\begin{array}{l}\text { The business processes are strategically } \\
\text { aligned in order to completely perceive their } \\
\text { capabilities. }\end{array}$ & \\
\hline & $\begin{array}{l}\text { There is a bi-directional relationship between } \\
\text { organizational strategy and business processes. }\end{array}$ & \\
\hline \multirow{3}{*}{$\begin{array}{l}\text { 3. Strategic } \\
\text { measurement of } \\
\text { business process }\end{array}$} & $\begin{array}{l}\text { The performance measurement is process- } \\
\text { oriented and disseminated. }\end{array}$ & \\
\hline & $\begin{array}{l}\text { The performance measurement integrates } \\
\text { activities and processes across the } \\
\text { departments. }\end{array}$ & \\
\hline & $\begin{array}{l}\text { The performance measurement deploys the } \\
\text { vision, mission and strategic goals from } \\
\text { business processes to operations. }\end{array}$ & \\
\hline 4. Process architecture & $\begin{array}{l}\text { The business processes are aligned with each } \\
\text { other hierarchically and with business strategy. }\end{array}$ & \\
\hline
\end{tabular}




\begin{tabular}{|c|c|}
\hline & $\begin{array}{l}\text { The business process architecture is articulated } \\
\text { in order to keep up with strategy changes. }\end{array}$ \\
\hline \multirow[t]{3}{*}{ 5. Stakeholders oriented } & $\begin{array}{l}\text { Stakeholders actively participate in business } \\
\text { process improvement initiatives. }\end{array}$ \\
\hline & $\begin{array}{l}\text { There are communication systems to promote } \\
\text { integration with stakeholders. }\end{array}$ \\
\hline & $\begin{array}{l}\text { The collaboration between stakeholders } \\
\text { generates value to those involved in business } \\
\text { processes. }\end{array}$ \\
\hline \multirow[t]{2}{*}{$\begin{array}{l}\text { 6. Process roles and } \\
\text { responsibilities }\end{array}$} & $\begin{array}{l}\text { Process roles and responsibilities are clear and } \\
\text { defined including all functions related to BPM. }\end{array}$ \\
\hline & The governance practices are institutionalized. \\
\hline $\begin{array}{l}\text { 7. BPM norms and } \\
\text { guidelines }\end{array}$ & $\begin{array}{l}\text { BPM norms and guidelines are well defined } \\
\text { and documented. }\end{array}$ \\
\hline \multirow{3}{*}{$\begin{array}{l}\text { 8. Process definition, } \\
\text { implementation and } \\
\text { documentation }\end{array}$} & The business process notation is standardized. \\
\hline & $\begin{array}{l}\text { The business process models are clear and } \\
\text { contain the main process information (inputs, } \\
\text { outputs, roles, etc). }\end{array}$ \\
\hline & $\begin{array}{l}\text { The employees are knowledgeable and have } \\
\text { access to business process models. }\end{array}$ \\
\hline \multirow[t]{2}{*}{ 9. Process optimization } & $\begin{array}{l}\text { There is systematic planning to identify and } \\
\text { implement business process improvements. }\end{array}$ \\
\hline & $\begin{array}{l}\text { There are resources available to apply } \\
\text { techniques and models of process } \\
\text { optimization, such as: PDCA cycle, Six } \\
\text { Sigma, etc. }\end{array}$ \\
\hline $\begin{array}{l}\text { 10. Information } \\
\text { technology }\end{array}$ & $\begin{array}{l}\text { There is an information system oriented to a } \\
\text { business process which address their } \\
\text { requirements. }\end{array}$ \\
\hline
\end{tabular}




\begin{tabular}{|c|c|}
\hline & $\begin{array}{l}\text { The information technology accelerates and } \\
\text { facilitates business process improvement and } \\
\text { innovation. }\end{array}$ \\
\hline & $\begin{array}{l}\text { The IT database is standardized and reflects } \\
\text { the real business processes. }\end{array}$ \\
\hline 11. Skills development & There is a BPM training program. \\
\hline & $\begin{array}{l}\text { There is an evaluation of employees' } \\
\text { knowledge about BPM. }\end{array}$ \\
\hline 12. Process leadership & $\begin{array}{l}\text { Process leaders feel motivated and adopt good } \\
\text { leadership and management practices. }\end{array}$ \\
\hline & $\begin{array}{l}\text { The process improvements are developed and } \\
\text { deployed in an effective manner by the person } \\
\text { in charge. }\end{array}$ \\
\hline $\begin{array}{l}\text { 13. Organizational } \\
\text { culture }\end{array}$ & $\begin{array}{l}\text { All employees feel free to contribute with } \\
\text { BPM. }\end{array}$ \\
\hline & Leaders show total engagement with BPM. \\
\hline & $\begin{array}{l}\text { The culture supports quick organizational } \\
\text { changes. }\end{array}$ \\
\hline
\end{tabular}

